\title{
SCIDiC
}

International Journal of Dentistry and Oral Science (IJDOS)

ISSN: $2377-8075$

\section{Preventive And Interceptive Need In Children Below 10 Years Of Age}

Research Article

Fahmida Binti Abd Rahman ${ }^{1}$, Nivethigaa $B^{2 *}$, Uma Maheshwari ${ }^{3}$

${ }^{1}$ Saveetha Dental College and Hospitals, Saveetha Institute of Medical and Technical Sciences, Chennai - 600 077, TN, India.

${ }^{2}$ Senior Lecturer, Department of Orthodontics, Saveetha Dental College, Saveetha Institute of Medical and Technical Sciences, Saveetha University, 162, Poonamallee High Road, Chennai - 600077, Tamil Nadu, India.

${ }^{3}$ Department of Oral Medicine and Radiology, Saveetha Dental College, Saveetha Institute of Medical and Technical Sciences, Saveetha University, 162, Poonamallee High Road, Chennai - 600077, Tamil Nadu, India.

\section{Abstract}

Interceptive orthodontics treatment is a procedure or intervention phase aiming for eliminating or reducing the need for complex treatment in permanent dentition. These interceptive measures are needed to prevent or avoid adverse occlusal and dental consequences, which are the negative effect for the early loss of primary molars because of nonnutritive habits. The aim of this study is to assess the preventive and interceptive need in children below 10 years old. A total of 41400 case records of patients were evaluated between the period of June 2019 to March 2020. The study was conducted on patients below 10 years old. Case records which were complete and data regarding dental or skeletal malocclusion were included for the study. Incomplete case records were excluded. Convenient sampling method was used and photographic verification was done for cross verification of data. All the data was verified by a single trained examiner. Chi square test was done and the association between age and different types of malocclusion was found to be statistically significant. Within the limit of our study, it could be concluded that prevalence for preventive and interceptive need among children below 10 years of age is relatively low at $6.03 \%$. Males had higher prevalence for preventive and interceptive needs compared to females. Children aged 8-10 years old had higher prevalence for malocclusions when compared to children aged 4-7 years old. Males had higher predilection for malocclusion especially crossbite in comparison to females.

Keywords: Children; Interceptive; Orthodontics; Preventive.

\section{Introduction}

The advantages for interceptive orthodontics treatment are reduction of protrusion, dental and skeletal malformations, reduction in terms of overjet, providing space for the eruption and can also correct the abnormal muscle morphology [1]. Interceptive orthodontic treatment does not always provide finished orthodontics treatment in permanent dentition. Several studies have suggested that technically planned interceptive treatment in mixed dentition might contribute to a significant decrease in treatment needs for children aged between 8-12 years old. Even though malocclusions are not life threatening but some would recommend the use of interceptive orthodontics treatment as a public health initiative in order to provide orthodontics treatment in areas where they are limited access and resources, reducing the cost in these underpriv- ileged areas. Many young children were commonly left untreated until the age of 12 years old. Forgetting that the young children are in the growth phase and that, over the years, the expression of growth can be modulated, especially in regard to dysfunctions that have already led to the development of deformations at a young age. Since these causes were not detected as early as possible, there is an even greater risk that existing dental malpositions and malocclusions will become worse over time. The severity of these problems can then be such that the extraction of permanent teeth with extended treatment time and more complicated treatment is frequently necessary. Previously our team has a rich experience in working on various research projects across multiple disciplines [2-16]. The aim of the current study was done to determine the prevalence or preventive and interceptive need in children below 10 years of age.

\section{*Corresponding Author:}

Nivethigaa B,

Senior Lecturer, Department of Orthodontics, Saveetha Dental College, Saveetha Institute of Medical and Technical Sciences, Saveetha University, 162, Poonamallee High Road, Chennai - 600077, Tamil Nadu, India.

Tel: +919524234613

E-mail: nivethigaab.sdc@saveetha.com

Received: May 28, 2021

Accepted: June 16, 202

Published: July 04, 2021

Citation: Fahmida Binti Abd Rahman, Nivethigaa B, Uma Maheshwari. Preventive And Interceptive Need In Children Below 10 Years Of Age. Int J Dentistry Oral Sci. 2021;8(7):30223025. doi: http://dx.doi.org/10.19070/2377-8075-21000615

Copyright: Nivethigaa $\mathbf{B}^{\circ}$ 2021. This is an open-access article distributed under the terms of the Creative Commons Attribution License, which permits unrestricted use, distribution and reproduction in any medium, provided the original author and source are credited. 


\section{Materials And Methods}

\section{Study design}

The present study was a retrospective study done in a university setting at a private dental college. A total of 41,400 case records of patients were evaluated and it was found that 214 patients matched our criteria and were included in the present study. Out of 214,125 were males and 89 of them were females. The advantages for this study setting is it can provide easy accessibility to data and provide a population with similar ethnicity. The inclusion criteria would be all patients and with a history of malocclusion meanwhile the exclusion criteria would be the incomplete case sheets and other history.

\section{Data collection}

Data was imported in the time period of June 2019 to March 2020. The study was conducted on all patients which were below 10 years old. Convenient sampling method was used and photographic verification was done for cross verification of data. All the data was verified by a single trained examiner. Ethical approval for this study was obtained from the institutional ethical committee.(SDC/SIHEC/2020/DIASDATA/ 0619-0320). Data regarding age, gender, presence of malocclusion were performed and the data was tabulated in Microsoft Excel. The imported data was analysed using SPSS software (IBM SPSS Statistics, Version 24.0, Amonk, NY: IBM Corp)

\section{Statistical analysis}

Descriptive statistics were used for data summarization. Chi square test was done to test the association between gender and types of malocclusion; malocclusion and age; and malocclusion and gender of children. Independent variables were gender and age and the dependent variable was the types of malocclusion. The level for a statistical significance was set at a $\mathrm{p}$ value $<0.05$.

\section{Results And Discussions}

According to the association between gender of children with skeletal and dental malocclusion, it can be seen that females are mostly affected with dental malocclusion $(34.58 \%$ ) compared to skeletal malocclusion (7.01\%). The prevalence for dental malocclusion $(52.34 \%)$ in males is also much higher than skeletal malocclusion (6.07\%). Chi square test was done and the $\mathrm{p}$ value was found to be 0.618 which was more than 0.05 . Hence, it was considered as statistically not significant (Figure 3). Based on the association between age of children and different types of malocclusion it can be concluded that children age 4-7 years old mostly affected with crossbite(7.48\%), open bite(4.67\%), maxillary deficiency $(1.87 \%)$, mandibular deficiency $(1.40 \%)$,spacing and crowding shared the same percentage values $(0.93 \%)$ followed by deep bite and proclination were the least affected $(0.47 \%)$. For children age 8-10 years old, it can be concluded that most of them had crossbite $(20.09 \%)$, crowding $(16.82 \%)$, open bite $(13.55 \%)$, proclination $(9.81 \%)$, spacing $(9.35 \%)$, mandibular deficiency (3.27\%), deep bite and horizontal mandibular excess (2.80\%) and horizontal maxillary excess $(1.40 \%)$ was the least type of malocclusion develop among the children. Chi square test was done and the $\mathrm{p}$ value was 0.042 which was more than 0.05 . Therefore, it was statistically significant (Figure 4). Our institution is passionate about high quality evidence based research and has excelled in various fields [17-27].

Prevalence for crossbite among children aged 8-10 years old is almost three times higher than children aged 4-7 years old. This finding is in accordance with a study done by Karaiskos et al [28] which stated that the prevalence of crossbite in older children

Figure 1. Bar graph represents the distribution of gender in children less than 10 years of age. $\mathrm{X}$ axis represents gender of the patients and $\mathrm{Y}$ axis represents number of children with various malocclusion. Males (black) $58.41 \%$ had higher prevalence for malocclusions compared to females (white) $41.59 \%$.

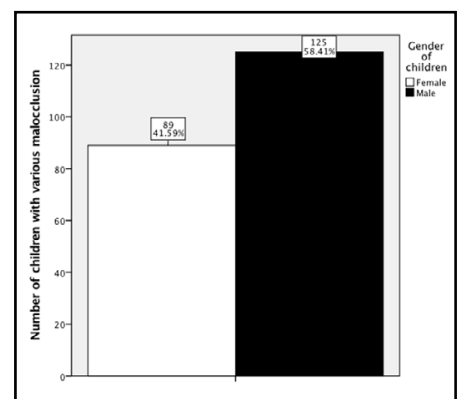

Figure 2. Bar graph represents the frequency distribution of different malocclusion among children. $\mathrm{X}$ axis represents various malocclusion and $\mathrm{Y}$ axis represents number of children with various malocclusion. Majority of the children had dental malocclusion compared to skeletal malocclusion and crossbite (yellow) is the most common dental malocclusion (27.57\%).

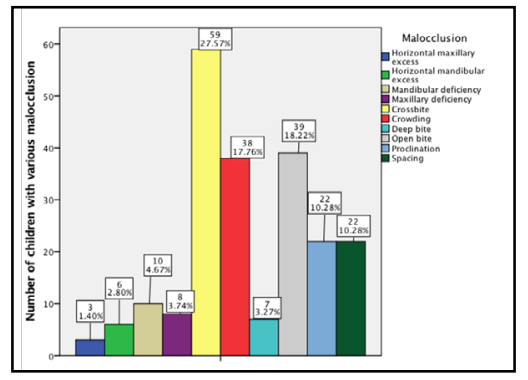


Figure 3. Bar graph represents gender of children association in children with skeletal and dental malocclusion. $\mathrm{X}$ axis represents gender of children and $\mathrm{Y}$ axis represents the number of children with various malocclusion. (Chi square test $\mathrm{p}$ value $-0.168>0.05$, hence statistically not significant). Male had higher prevalence for dental malocclusion compared to females although significantly not associated.

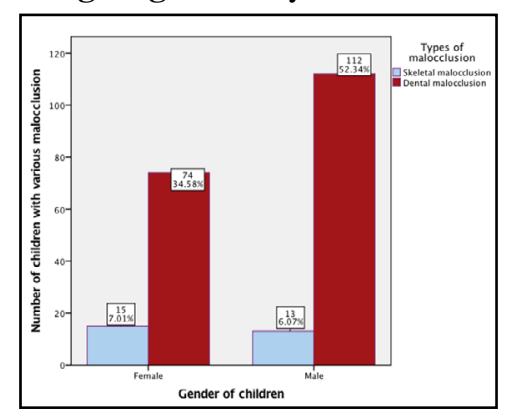

Figure 4. Bar graph represents the association of age of children with different types of malocclusion. $\mathrm{X}$ axis represents malocclusion and $Y$ axis represents the number of children with various malocclusion. (Chi square test $p$ value -0.042 $<0.05$, hence statistically significant). Children aged 8-10 years old had higher prevalence for crossbite when compared to children aged 4-7 years old and hence there is significant association.

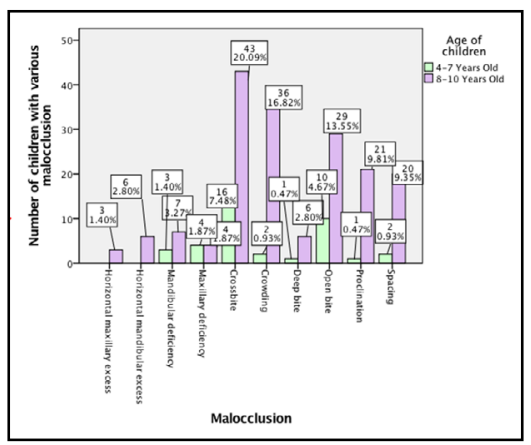

Figure 5. Bar graph represents the association of types of malocclusion and gender of children. $\mathrm{X}$ axis represents malocclusion and $\mathrm{Y}$ axis represents number of children with various malocclusion. (Chi square test $\mathrm{p}$ value- $\mathbf{0 . 2 5 5}>\mathbf{0 . 0 5}$, hence statistically not significant). Males(Black) had higher prevalence for malocclusion especially crossbite, followed by crowding in comparison to females(White), hence there is no significant association.

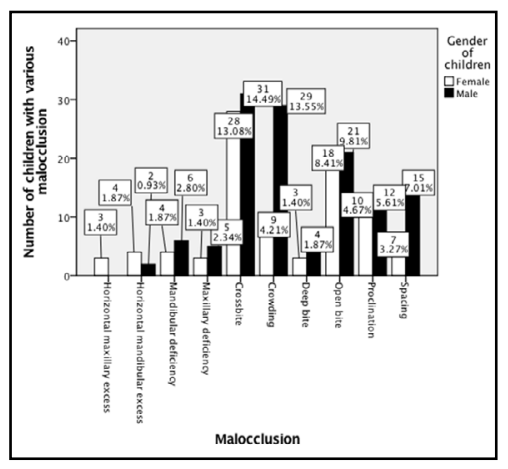

aged 9 years old is slightly higher than children aged 6 years old with a percentage value of $11.9 \%$ and $10.5 \%$ respectively. This finding could be attributed to the fact that the number of examined was higher in older children or could be due to older children visiting dental clinics more than younger children.

Limitations of this study is that due to small sample size included. Since it was a retrospective study, there was also possible for manual errors during data collection or data analysis. Furthermore, it was only based on a single institutional. Further studies to be performed with huge sample size and confirmation from few examiners were required to avoid manual error during data collection or data analysis. In addition, it should also cover multiple cities and centres.

\section{Conclusions}

Within the limit of our study, it could be concluded that prevalence for preventive and interceptive need among children below 10 years of age is relatively low at $0.06 \%$. Males had higher prevalence for preventive and interceptive needs compared to females. Children aged 8-10 years old had higher prevalence for malocclusions when compared to children aged 4-7 years old. Hence early diagnosis and treatment at the appropriate time utilising the leftover growth can aid in intercepting various malocclusion.

\section{Acknowledgments}

We thanked Saveetha Dental College and Hospitals for providing data for the current study. 


\section{References}

[1]. Popovic N, Drinkuth N, Toll DE. Prevalence of class III malocclusion and crossbite among children and adolescents with craniomandibular dysfunction. J Orofac Orthop. 2014 Jan 1;75(1):36-41.

[2]. Hafeez N. Accessory foramen in the middle cranial fossa. Res J Pharm Technol. 2016;9(11):1880-2.

[3]. Krishnan RP, Ramani P, Sherlin HJ, Sukumaran G, Ramasubramanian A, Jayaraj G, et al. Surgical Specimen Handover from Operation Theater to Laboratory: A Survey. Ann Maxillofac Surg. 2018 Jul-Dec;8(2):234-238. Pubmed PMID: 30693238

[4]. Somasundaram S, Ravi K, Rajapandian K, Gurunathan D. Fluoride Content of Bottled Drinking Water in Chennai, Tamilnadu. J Clin Diagn Res. 2015 Oct;9(10):ZC32-4.Pubmed PMID: 26557612.

[5]. Felicita AS. Orthodontic extrusion of Ellis Class VIII fracture of maxillary lateral incisor - The sling shot method. Saudi Dent J. 2018 Jul;30(3):265269.Pubmed PMID: 29942113

[6]. Kumar S, Rahman R. Knowledge, awareness, and practices regarding biomedical waste management among undergraduate dental students. Asian J Pharm Clin Res. 2017;10(8):341.

[7]. Gurunathan D, Shanmugaavel AK. Dental neglect among children in Chennai. J Indian Soc Pedod Prev Dent. 2016 Oct 1;34(4):364.

[8]. Sneha S. Knowledge and awareness regarding antibiotic prophylaxis for infective endocarditis among undergraduate dental students. Asian J Pharm Clin Res. 2016 Oct 1:154-9.

[9]. Dhinesh B, Lalvani JI, Parthasarathy M, Annamalai K. An assessment on performance, emission and combustion characteristics of single cylinder diesel engine powered by Cymbopogon flexuosus biofuel. Energy Convers. Manag. 2016 Jun 1;117:466-74.

[10]. Choudhari S, Thenmozhi MS. Occurrence and Importance of Posterior Condylar Foramen. Res J Pharm Technol. 2016;9(8):11-43.

[11]. Paramasivam A, Vijayashree Priyadharsini J, Raghunandhakumar S. N6adenosine methylation $(\mathrm{m} 6 \mathrm{~A})$ : a promising new molecular target in hypertension and cardiovascular diseases. Hypertens Res. 2020 Feb;43(2):153154.Pubmed PMID: 31578458 .

[12]. Wu F, Zhu J, Li G, Wang J, Veeraraghavan VP, Krishna Mohan S, et al. Biologically synthesized green gold nanoparticles from Siberian ginseng induce growth-inhibitory effect on melanoma cells (B16). Artif Cells Nanomed Biotechnol. 2019 Dec;47(1):3297-3305.Pubmed PMID: 31379212.

[13]. Palati S, Ramani P, Shrelin HJ, Sukumaran G, Ramasubramanian A, Don KR, et al. Knowledge, Attitude and practice survey on the perspective of oral lesions and dental health in geriatric patients residing in old age homes. Indian J Dent Res. 2020 Jan-Feb;31(1):22-25.Pubmed PMID: 32246676

[14]. Saravanan M, Arokiyaraj S, Lakshmi T, Pugazhendhi A. Synthesis of silver nanoparticles from Phenerochaete chrysosporium (MTCC-787) and their antibacterial activity against human pathogenic bacteria. Microb Pathog. 2018 Apr;117:68-72.Pubmed PMID: 29427709.

[15]. Govindaraju L, Gurunathan D. Effectiveness of Chewable Tooth Brush in Children-A Prospective Clinical Study. J Clin Diagn Res. 2017
Mar;11(3):ZC31-ZC34.Pubmed PMID: 28511505.

[16]. Vijayakumar Jain S, Muthusekhar MR, Baig MF, Senthilnathan P, Loganathan S, Abdul Wahab PU, et al. Evaluation of Three-Dimensional Changes in Pharyngeal Airway Following Isolated Lefort One Osteotomy for the Correction of Vertical Maxillary Excess: A Prospective Study. J Maxillofac Oral Surg. 2019 Mar;18(1):139-146.Pubmed PMID: 30728705.

[17]. Vijayashree Priyadharsini J. In silico validation of the non-antibiotic drugs acetaminophen and ibuprofen as antibacterial agents against red complex pathogens. J Periodontol. 2019 Dec;90(12):1441-1448.Pubmed PMID: 31257588.

[18]. Pc J, Marimuthu T, Devadoss P, Kumar SM. Prevalence and measurement of anterior loop of the mandibular canal using CBCT: A cross sectional study. Clin Implant Dent Relat Res . 2018 Apr 6;20(4):531-4.

[19]. Ramesh A, Varghese S, Jayakumar ND, Malaiappan S. Comparative estimation of sulfiredoxin levels between chronic periodontitis and healthy patients - A case-control study. J Periodontol. 2018 Oct;89(10):1241-1248.Pubmed PMID: 30044495.

[20]. Ramadurai N, Gurunathan D, Samuel AV, Subramanian E, Rodrigues SJ. Effectiveness of 2\% Articaine as an anesthetic agent in children: randomized controlled trial. Clin. Oral Investig. 2019 Sep;23(9):3543-50.

[21]. Sridharan G, Ramani P, Patankar S, Vijayaraghavan R. Evaluation of salivary metabolomics in oral leukoplakia and oral squamous cell carcinoma. J Oral Pathol Med. 2019 Apr;48(4):299-306.

[22]. Ezhilarasan D, Apoorva VS, Ashok Vardhan N. Syzygium cumini extract induced reactive oxygen species-mediated apoptosis in human oral squamous carcinoma cells. J Oral Pathol Med. 2019 Feb;48(2):115-121.Pubmed PMID: 30451321.

[23]. Mathew MG, Samuel SR, Soni AJ, Roopa KB. Evaluation of adhesion of Streptococcus mutans, plaque accumulation on zirconia and stainless steel crowns, and surrounding gingival inflammation in primary molars: randomized controlled trial. Clin Oral Investig. 2020 Sep;24(9):1-6.Pubmed PMID: 31955271.

[24]. Samuel SR. Can 5-year-olds sensibly self-report the impact of developmental enamel defects on their quality of life? Int J Paediatr Dent. 2021 Mar;31(2):285-286.Pubmed PMID: 32416620.

[25]. R H, Ramani P, Ramanathan A, R JM, S G, Ramasubramanian A, et al. CYP2 C9 polymorphism among patients with oral squamous cell carcinoma and its role in altering the metabolism of benzo[a]pyrene. Oral Surg Oral Med Oral Pathol Oral Radiol. 2020 Sep;130(3):306-312.Pubmed PMID: 32773350 .

[26]. Chandrasekar R, Chandrasekhar S, Sundari KKS, Ravi P. Development and validation of a formula for objective assessment of cervical vertebral bone age. Prog Orthod. 2020 Oct 12;21(1):38.Pubmed PMID: 33043408.

[27]. Vijayashree Priyadharsini J, Smiline Girija AS, Paramasivam A. In silico analysis of virulence genes in an emerging dental pathogen A. baumannii and related species. Arch Oral Biol. 2018 Oct;94:93-98.Pubmed PMID: 30015217.

[28]. Karaiskos N, Wiltshire WA, Odlum O, Brothwell D, Hassard TH. Preventive and interceptive orthodontic treatment needs of an inner-city group of 6and 9-year-old Canadian children. J Can Dent Assoc. 2005 Oct;71(9):649. Pubmed PMID: 16271161. 